\title{
微粉炭多量吹き込み時のレースウェイでのコークスの 劣化挙動に及ぼすコークスの反応性と強度の影響
}

\author{
笠井 昭人*・宮川 一也*・上條 綱雄*・木口 淳平*・清水 正賢*
}

The Effect of Reactivity and Strength of Coke on Coke Degradation in the Raceway at High Rate of Pulverized Coal Injection

Akito Kasai, Kazuya Miyagawa, Tsunao Kamijo, Junpei Kiguchi and Masakata Shimizu

Synopsis : In order to clear the effect of coke quality on coke degradation in a blast furnace raceway at high rate of pulverized coal injection, experiments by a hot model simulating the raceway were carried out. The results were as follows.

(1) Reactivity and strength of coke effect on combustion behavior of pulverized coal and coke in the raceway, coke degradation in the raceway and the raceway structure.

(2) Using high reactivity coke, thickness of reacted layer near the lump coke surface is thin

(3) Using high reactivity and high strength coke, coke degradation in the raceway is suppressed.

Key words : blast furnace ; raceway ; coke ; degradation ; reactivity ; drum index ; pulverized coal injection.

\section{1. 緒言}

近年，溶銑コストの大幅な低減を目指して，高炉への微 粉炭吹き込みが指向されている1。既に一部の高炉では微粉

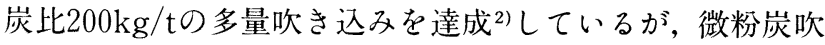
き込及量の増大とともに，炉芯の不活性化あるいは炉下部 現象の変化に起因すると思われる炉下部圧損の上昇や送風 圧変動が増大寸る傾向 ${ }^{2-4)}$ にある。微粉炭多量吹き込及操業 を長期間・安定して継続するには，炉下部での通気・通液 性を確保する必要があり，そのためには，（1）レースウェ イでのコークスの劣化の抑制, (2) 未燃烵微粉炭の発生及 び蓄積の抑制，（3）炉上部でのコークスの劣化の抑制及び 発生粉の炉下部への流入の抑制等が重要となる。

従来より，レースウェイでのコークスの劣化の抑制と微 粉炭の燃焼性の向上を目的に，レースウェイ部を模擬した 試駼燃焼炉を用いた研究5-10)が多数行われている。微粉炭吹 き込み時のレースウェイ内での反応は微粉炭とコークスの 競合反応であり，この中で特に微粉炭の燃焼挙動について は, 微粉炭の性状6-8)や衝風条件7,9,10)の影響について基礎的 に多数検討されている。

一方，コークスの反応・劣化挙動については，オールコ ークス操業時のレースウェイでの燃焼挙動とコークスの劣 化挙動に及ばすコークスの冷間強度や反応後強度の影響と いう物理的挙動に関する検討例は多(11-13)ものの，コーク スの反応性の影響に関する研究例12)は少ない。さらに, 微粉 炭多量吹き込み時については，コークス粒子のレースウェ
イ内での滞留時間増加による粉化量の増大が龧念されるが, レースウェイでのコークスの劣化とコークス品位の関係 ${ }^{14)}$ に ついては，いまだ末解明な点が多い。

そこで本研究では，コークス充填型の試験燃焼炉 6 ,7)を用 いて, 微粉炭多量吹き込み時のレースウェイ内でのコーク スの劣化挙動に及ぼすコークスの反応性と強度の影響につ いて検討した。

\section{2. 実験方法}

\section{$2 \cdot 1$ 実験装置}

実験装置は，高炉レースウェイ部を模擬したコークス充 填型の試駼燃焼炉6,7)である。装置概略図をFig. 1 に示す。炉

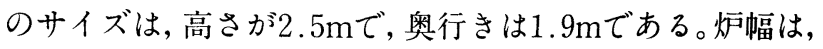

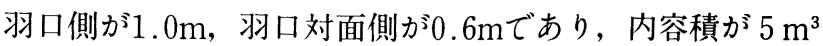
の扇形炉である。羽口は，内径 $80 \mathrm{~mm}$ の水冷羽口である。炉 頂のコークスホッパーには超音波レベル計が設けてあり， コークスの降下速度を計測できる。コークス充填層の下に は砂が充塡してあり, 砂をロータリーフィーダーで切り出 すことにより炉芯の更新が模擬できる。また，羽口対面よ りプローブを挿入して，ガスとダストのサンプリングが可 能である。

\section{$2 \cdot 2$ 試料}

\section{(1) コークス}

使用したコークスの性状をTable 1 に示す。コークスは, ドラム強度指数 $\mathrm{DI}_{15}^{150}$ 反応性RIをそれぞれ変更させており， 


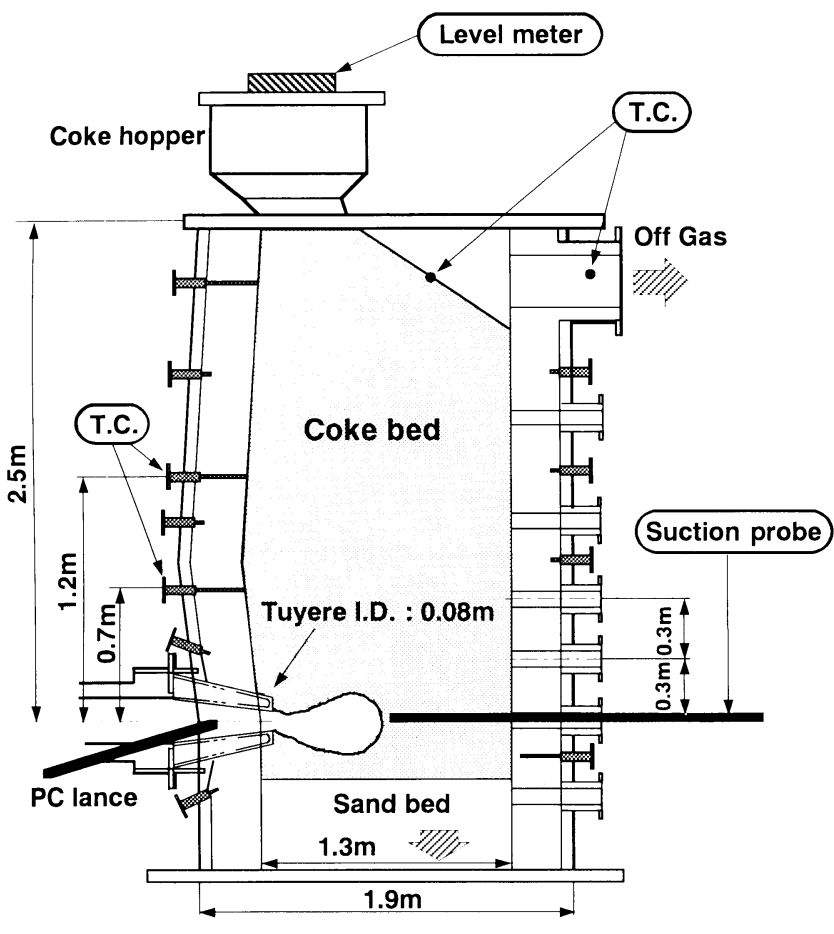

Fig. 1. Experimental furnace.

Table 1. Properties of coke.

\begin{tabular}{|c|cccccc|}
\hline Coke No. & $\begin{array}{c}\mathrm{DI}_{15}^{150} \\
(-)\end{array}$ & $\begin{array}{c}\mathrm{I}_{13.2}^{600} \\
(-)\end{array}$ & $\begin{array}{c}\mathrm{RI} \\
(-)\end{array}$ & $\begin{array}{c}\mathrm{RSI} \\
(-)\end{array}$ & $\begin{array}{c}\text { Ash } \\
(\%)\end{array}$ & $\begin{array}{c}\text { Porosity } \\
(\%)\end{array}$ \\
\hline A & 85.2 & 88.8 & 23.0 & 70.5 & 11.2 & 45.0 \\
B & 84.5 & 85.4 & 35.6 & 53.5 & 11.5 & 45.5 \\
C & 81.9 & 83.6 & 40.2 & 43.2 & 11.2 & 44.4 \\
\hline
\end{tabular}

Table 2. Properties of pulverized coal.

\begin{tabular}{|c|c|c|}
\hline \multicolumn{3}{|c|}{ Proximate analysis } \\
\hline Volatile matter & Ash & Fixed carbon \\
\hline 34.4 & 9.2 & 56.4 \\
\hline
\end{tabular}

必分と気孔率はほぼ一定である。コークスの粒度は $8 \mathrm{~mm} ２ 0$ $\mathrm{mm}$ で，平均径は約 $14.5 \mathrm{~mm}$ である。

ここで, ドラム強度指数 $\mathrm{DI}_{15}^{150}$ は, $25 \mathrm{~mm}$ 以上のュークス 10 $\mathrm{kg}$ をJISドラム試験機を用いて150回転した後の $15 \mathrm{~mm}$ 以上の 重量割合である。I型ドラム強度指数 $\mathrm{I}_{13.2}^{600}$ は, $16 \mathrm{~mm} \sim 19 \mathrm{~mm}$ のコークス $200 \mathrm{~g}$ を型ドラム試験機 $(\phi 130 \mathrm{~mm} \times 700 \mathrm{~mm})$ を用 いて600回転した後の $13.2 \mathrm{~mm}$ 以上の重量割合である。反応 性RIは, $20 \pm 1 \mathrm{~mm}$ のコークス $200 \mathrm{~g}$ t $1100^{\circ} \mathrm{C} て ゙ 5 \mathrm{Nl} / \mathrm{min} の \mathrm{CO}_{2}$ ガスと 2 時間反応させた後の重量減少割合である。反応後 強度RSIは, RI測定後のコークスをI型ドラム試験機で600回 転した後の $9.52 \mathrm{~mm}$ 以上の重量割合である。

\section{( 2 ) 微粉炭}

使用した微粉炭の分析值をTable 2 に示す。微粉炭の平均
Table 3. Experimental conditions.

\begin{tabular}{|l|l|}
\hline Blast flow rate & $720 \mathrm{Nm}^{3} / \mathrm{h}$ \\
Blast temperature & $1050^{\circ} \mathrm{C}$ \\
Oxygen enrichment & $0 \%$ \\
Pulverized coal injection rate & $144 \mathrm{~kg} / \mathrm{h}, 200 \mathrm{~kg} / \mathrm{t}$ \\
\hline
\end{tabular}

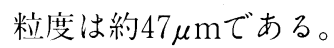

\section{$2 \cdot 3$ 実験条件}

燃焼試験時の衝風条件をTable 3 に亦寸。微粉炭吹き込み 量 $144 \mathrm{~kg} / \mathrm{h}$ は微粉炭比 $200 \mathrm{~kg} / \mathrm{t}$ に朴米する。

\section{$2 \cdot 4$ 実験項目と方法}

(1) 燃焼試験中のサンプリング

レースウエイ内の燃焼挙動が尘常状態に達した後，吸引 サンプリングにより羽日レベルでのガス組成分布と羽日、. $600 \mathrm{~mm}$ レベルでのガス中のダスト濃度(単仿吸引ガス量当た りのダストの重量) を测定した。

( 2 ) 炉内容物の解体調査

レースウエイ近傍での通気性を検咕するため, 燃焼試騃 終了後に炉内を筃素雲囲気で冷却し, 解体調枯によりコー クスの粒度分布とレースウェイシェル（解体調枯時にレース ウェイの周囲に認識できるコークス粒子と微粉炭炏分由来 の溶融物が一体となった嗀状の層》)のサイズを測走した。

ユークス粉と末燃焼微粉炭を分離して検討するため，採 取粉のサイズを0.3mm前後で分離した。末燃焼微粉炭とコ 一クス粉からなる $0.3 \mathrm{~mm}$ 以下の採取粉を微粉，コークス粉 のみからなる0.3mm〜5.0mmの採取粉を微粒とした。また， 塊コークスの平均径は, 微粉と微粒の影響を除いた $5 \mathrm{~mm}$ 上のコークスについて求めた。

( 3 ) コークス塊内部の反応摔分布

I型ドラム試験機を用いてコークスを顺転るる, コーク スは表面から均一に粉化するとして，コークス塊内部の反 応率は，所定回数回転した時に発伴ししたュークス粉の兏分 量の収支から求めた。

試料は, 解体調查時に羽门レベルで塊コークスの平均径 が最も低下していた位置(羽口先150〜300 mm)から採取した ユークスのうち, $11.2 \mathrm{~mm} \sim 13.2 \mathrm{~mm}$ 塊コークス 10 個であ る。

\section{3. 実験結果}

微粉炭の炭種と衝風条件が一定のもとでコークスの品位 を変更した燃焼試験を行い, 微粉炭多量吹き込み時のレー スウェイでの燃焼挙動とコークスの劣化举動に及ぼすュー クス品位の影響について検討した。

\section{$3 \cdot 1$ 燃焼挙動}

\section{(1) 微粉炭の燃焼率}

コークスの降下速度の变化から推走 ${ }^{6,7}$ した微粉炭の然焼 率をFig. 2 に示す。微粉炭の燃焼率はコークス品位により若 


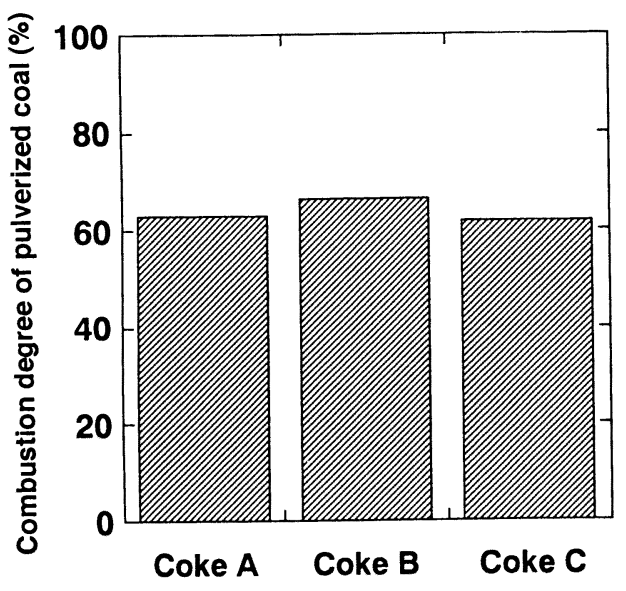

Fig. 2. Effect of coke quality on combustion degree of pulverized coal.

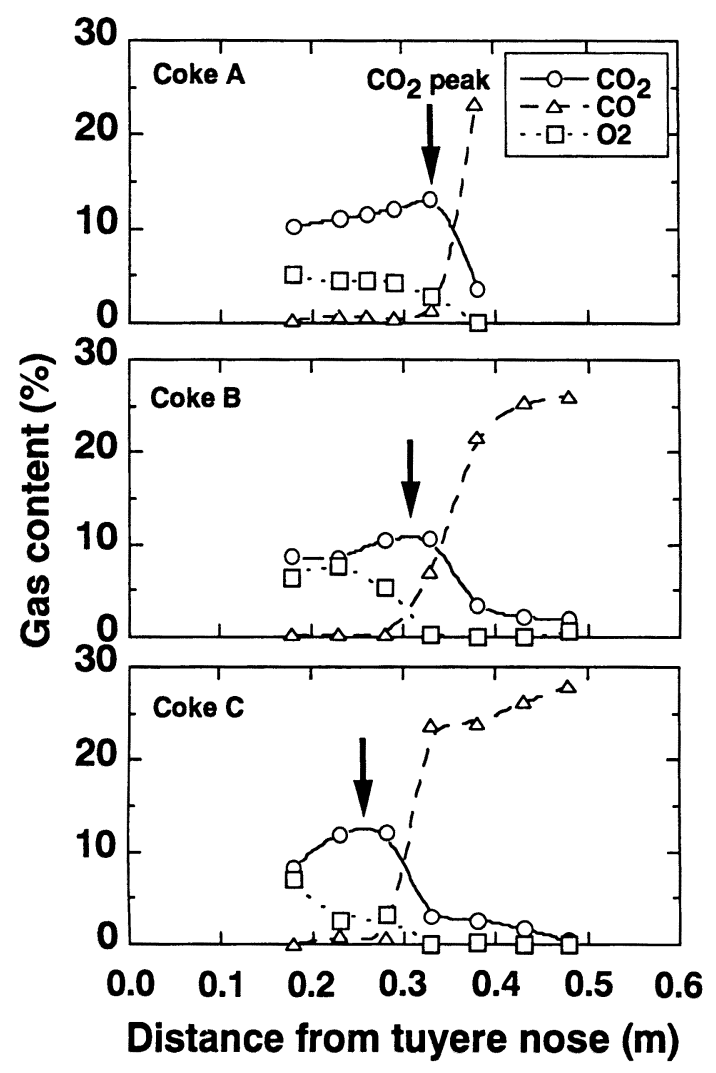

Fig. 3. Distributions of gas content at tuyere level.

干変化しており, Bコークス使用時が $66.6 \%$ 最も高く, A コークスとCコークスを使用した時はそれぞれ $63.1 \%$ \% 62.0 \%で，ほぼ同等である。

\section{(2)ガス組成分布}

羽日レベルでのガス組成分布をFig. 3 に示す。羽口レベル でのガス組成分布はユークス品位により変化している。ガ ス温度の最茼位置 (燃焼焦点) とほぼ一致する $\mathrm{CO}_{2}$ 濃度のピー クの位置》は，RIが上暞すると羽日側に移行している。

\section{3・2 コークスの劣化挙動}

(1) ダスト濃度分布

羽口上 $600 \mathrm{~mm}$ レベルでのガス中のダスト濃度分布をFig.

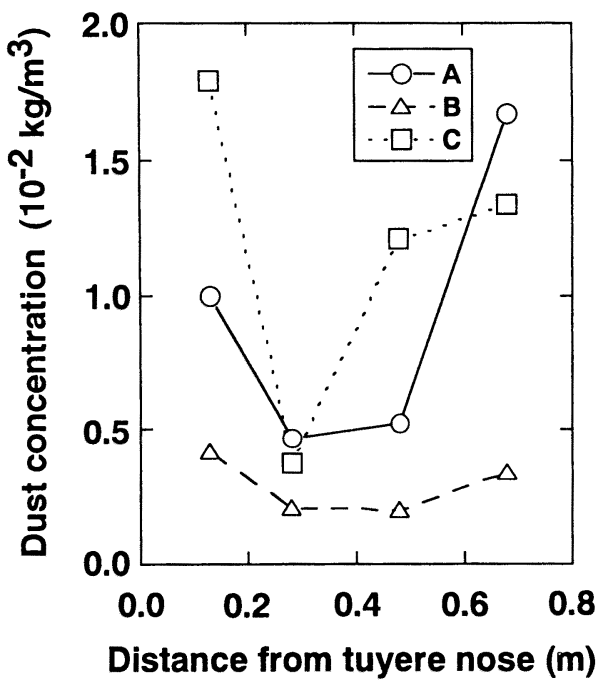

Fig. 4. Distributions of dust concentration at $0.6 \mathrm{~m}$ above tuyere level.

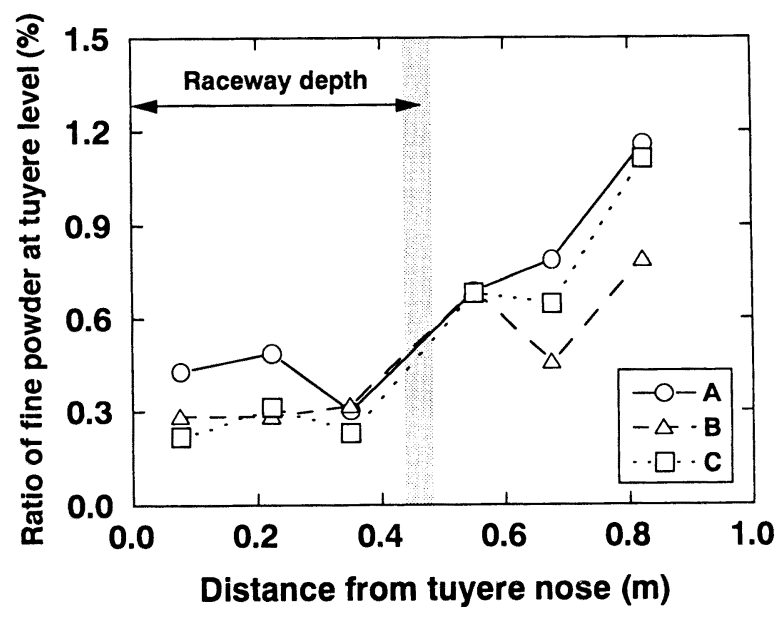

Fig. 5. Distributions of fine powder at tuyere level.

4 に示す。ダスト濃度はコークス品位により変化している。 ダス卜濃度は, 微粉炭の燃焼率が最も高いBユークス使用時 に少なくなっている。また, 羽口先からの距離の影響を見 ると，いずれのコークスを使用した時も，羽口先 $130 \mathrm{~mm}$ と $680 \mathrm{~mm}$ でダスト濃度は増加している。

\section{( 2 ) 微粉分布}

羽口レベルでの0.3mm以下の微粉分布(採取試料全量に占 める微粉の重量割合分布) をFig. 5 に示す。ここで，レース ウエイシェルを境界としたレースウェイサイズは, $440 \mathrm{~mm}$ 〜 480mmである。羽口先からの距離の影響を見ると，いず れのコークスを用いた場合も，微粉はレースウェイの奥で 増加している。微粉の発生量は $1 \%$ 程度とわずかであるが, コークス品位の影響を見ると, A ニークス使用時に最も多く なっている。

\section{(3) 微粒分布}

羽口レベルでの0.3mm〜 $5.0 \mathrm{~mm}$ の微粒分布(採取試料全 量に占める微粒の重量割合分布) をFig. 6 に示す。DI ${ }_{15}^{150}$ が同 


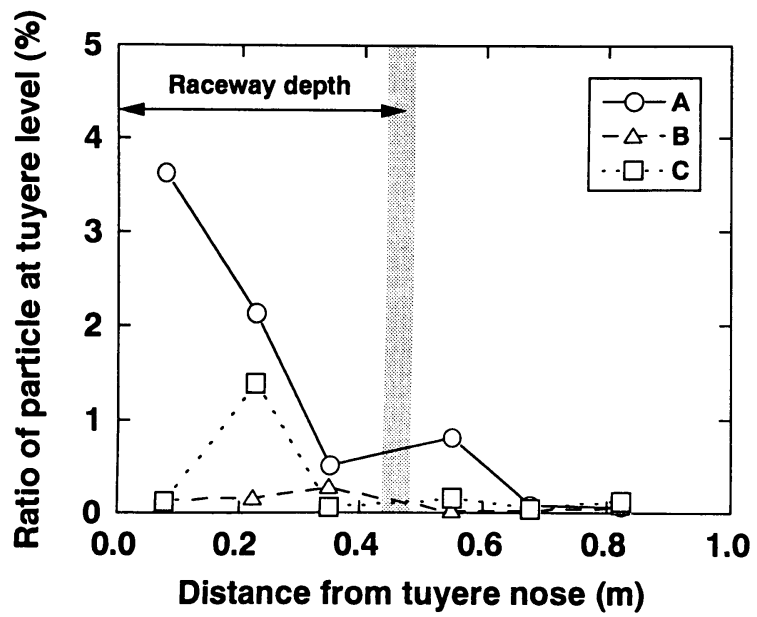

Fig. 6. Distributions of particle at tuyere level.

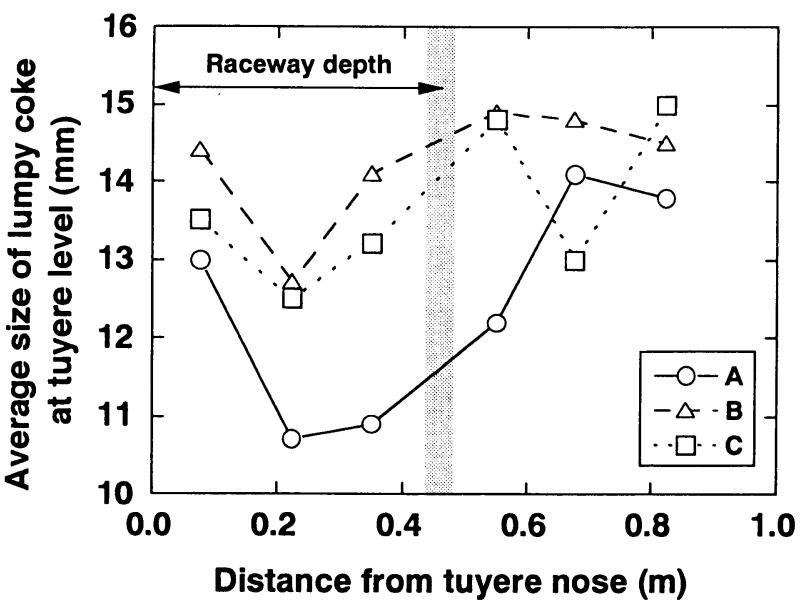

Fig. 7. Distributions of average size of lumpy coke at tuyere level.

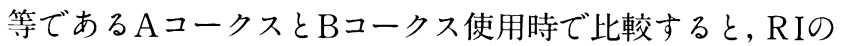
低い $\mathrm{A}$ ユークス使用時にレースウェイ前半部で微粒の発生量 が大きく増加している。一方, RIの高いBユークス使用時に は，微粒はほとんぞ発生していない。AコークスとBコーク スに比してDI ${ }_{15}^{150}$ が大幅に小さく, RIが最も高いCユークスを 使用すると, レースウェイ中間部で微粒が多少発生してい る。

（4）塊コークスの平均径分布

羽ロレベルでの $5 \mathrm{~mm}$ 以上塊コークスの平均径分布を Fig. 7 に示す。A $\mathrm{A}$ ニークス使用時に,レースウェイ後半部からレースウェイ の奥で塊コークスの平均径が大きく低下している。Cユーク スを使用すると，塊コークスの平均径は，Bコークス使用時 に比してわずかに低下しているものの, A ニークス使用時ほ ぞは低下していない。

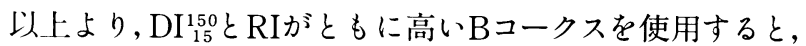
レースウェイでのコークスの劣化が少なく，微粉炭の燃燒 率が高くなっている。一方，DI ${ }_{15}^{15}$ は高いがRIが低いAコー
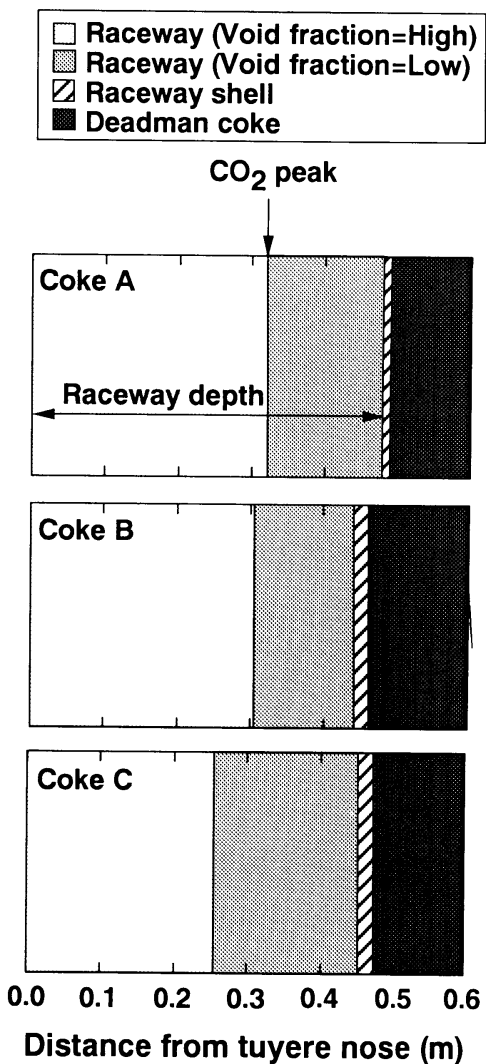

Fig. 8. Effect of coke quality on raceway structure.

クスを使用すると，コークスは激しく劣化している。また， $\mathrm{DI}_{15}^{150}$ は低いがRIが最も高いCユークスを使用寸ると, A コー クス使用時ほぞは劣化していない。

\section{4. 考察}

\section{$4 \cdot 1$ レースウェイ構造}

羽口レベルでのガス組成分布とレースウェイサイズをも とに検討したレースウェイ構造に及ぼすコークス品位の影 響者Fig. 8 に示寸。微粉炭の炭種と衝風条件が一定でも, コ 一クス品位に依存して燃焼挙動とコークスの劣化挙動が変 化し，レースウェイ構造が大きく変化している。すなわち， $\mathrm{A}$ ユークス使用時は， B，Cユークス使用時に比してレース ウェイサイズが大きい(レースウェイサイズ： $\mathrm{A}=480 \mathrm{~mm}$, $\mathrm{B}=440 \mathrm{~mm}, \mathrm{C}=450 \mathrm{~mm})$ が，これはレースウェイ内のコー クス粒径が小さい(羽ロレベルでの $5 \mathrm{~mm}$ 以上の塊コークス 平均径の羽口先 $0 \sim 400 \mathrm{~mm}$ での平均值: $\mathrm{A}=11.4 \mathrm{~mm}, \mathrm{~B}=$ $13.7 \mathrm{~mm}, \mathrm{C}=13.1 \mathrm{~mm}) こ と と$ 関係づけられる。

レースウェイは，空隙率が85\%以上のガスコア領域と空 隙率が $85 \%$ 程度から50\%程度まで直線的に低下していく領 域から構成される ${ }^{15)}$ 。また,レ一スウェイ軸方向のガス組成 分布を考えると, $\mathrm{CO}_{2}$ 濃度のピークの位置は $\mathrm{O}_{2}$ 濃度の減少位 置 $と$ CO濃度の増加位置に一致する。レースウェイ内でのCO ガスの発生は，レースウェイ内にコークスが存在し，ソリ 
ユーション・ロス反応が起きていることを示唆している。 従って, $\mathrm{CO}_{2}$ 濃度のピークの位置はレースウェイ内でューク スの空隙率が低下し始める位置とみなすことができる。 $\mathrm{CO}_{2}$ 濃度のピークの位置とレースウェイ内でのコークスの空隙 率の関係から，コークス品位とコークスの反応劣化による 粒径低下の結果がレースウエイ構造に大きな影響を及ぼし ていると推定できる。

さらに, $\mathrm{CO}_{2}$ 濃度のピークの位置 (燃焼焦点) はRIに依存し， RIが高い方が燃焼焦点は羽口側に近づく。また，RIの上昇 によりコークスの燃焼 (酸化) 速度が増加することから, RI の上昇は燃焼領域の昇温を早め, 微粉炭の昇温々燃焼率の 向上に寄与すると考えられる ${ }^{16)}$ 。しかし, 微粉炭の燃焼率は ユークスとの競合反応およびレースウェイ内の滞留時間に 依存することから，レースウエイ構造にも影響されると推 察できる。

\section{$4 \cdot 2$ コークスの劣化}

コークス塊内部の反応率分布をFig.9に示す。相対半径 $r / r_{o}$ は, 解体調查時に採取した塊コークスの半径 $\mathrm{r}_{0}(\mathrm{~m})$ と中心か らの距離 $\mathrm{r}(\mathrm{m})$ の比である。

RIの高いBコークスとCユークスを使用した時の反応率分 布はほぼ一致しており，この場合のレースウェイ内でのコ 一クスの反応は塊コークスの表面に集中している。従って, $\mathrm{B}$ ユークスとCユークス使用時で微粒分布と塊コークス平均 径に差がでたのは，DI ${ }_{15}^{150} に$ 代表される限界強度の差による と推察される。一方, Aユークスを使用した場合, レースウ エイという高温な領域でも反応がコークス塊内部まで進行 しており，その結果反応した領域である反応劣化層が厚く なっている。従って，Bユークス使用時に比してAコークス 使用時に微粒が発生し塊コークス平均径が低下したのは, $\mathrm{DI}_{15}^{150}$ に代表される反応前の限界強度が高くても, 反応速度 の差異によりコークス塊内部まで反応が進行し, 限界強度 以下の領域が厚くなったことに起因していると推察される。

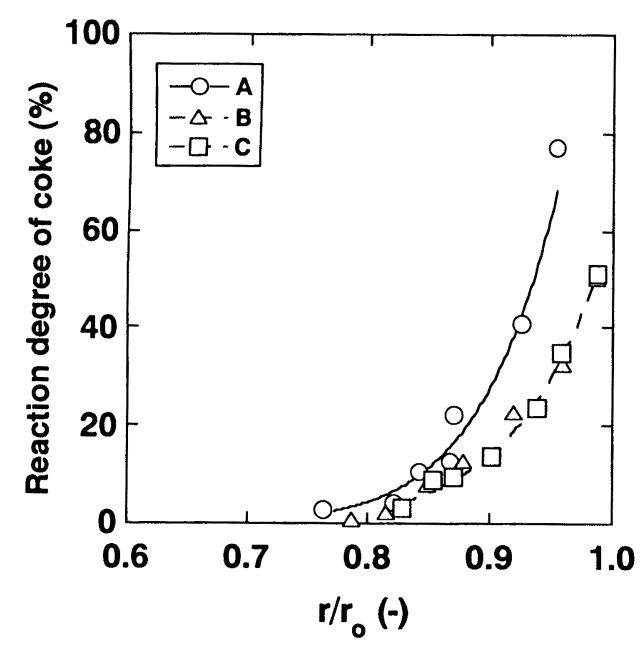

Fig. 9. Distributions of reaction degree in lumpy coke sampled in raceway.
また, Aコークスを使用した時にはレースウェイサイズが最 も大きくなっていることから，コークスのレースウェイ内 移動距離の増加による機械的な衝撃力の増加も微粒の多量 発生と塊コークス平均径の低下に寄与したと推定できる。

以上より， $\mathrm{DI}_{15}^{150}$ が一定な場合, RIが高いコークスを使用 すると, レースウェイでのコークスの反応は塊コークスの 表面に集中し，しかもレースウェイサイズが小さく，コー クスのレースウエイでの移動距離が短いため, 塊コークス の劣化は少なくなる。またこの時, 微粉炭の燃鈥率が向上 し，ダスト濃度も少なくなる。一方，RIが低いコークスを 使用すると，レースウェイという高温な領域でもコークス 塊内部まで反応が進行し，しかもレースウエイサイズが大 きく，コークスのレースウエイ内移動距離が長いため, 機 械的な衝撃力の増加により微粒が多量に発生し，塊コーク スの平均径が小さくなる。

従って, 微粉炭多量吹き込み時のレースウェイでのコー クスの劣化を抑制し，炉下部での通気性を確保するには， $\mathrm{DI}_{15}^{150}$ が高く，RIも高いコークスの使用が有効である。さら に, 高炉内でのソリューション・ロス反応量は一定で, 限 界強度以下になったコークスの反応層が高炉内を降下中に 表面より剝離すると仮定したシミュレーション計算からも RIが高いコークスの方が破壊後の粒径が大きくなっている17) ことから，レースウェイ部だけでなく，高炉全体でのコー クスの劣化抑制にもRIの高いコークスの使用は有効と考え られる。今後は, 高強度で高反応性のコークス製造方法に ついても検討していく必要がある。

\section{5. 結言}

微粉炭多量吹き込み時のレースウェイでのコークスの劣 化を抑制し，炉下部での通気性を確保することを目的に， ユークス充填型の試験燃焼炉を用いて，微粉炭多量吹き込 み時のレースウェイ内でのコークスの劣化挙動に及ぼすコ 一クスの反応性と強度の影響について検討し，以下の知見 を得な。

（1）コークスの反応性と強度は，レースウェイでの微粉 炭とコークスの燃焼挙動，コークスの劣化挙動に影響する とともに，レースウェイ構造にも大きく寄与する。

( 2 ) 高強度で高反応性のコークスを使用すると, 微粉炭 の燃焼率が若干向上する。

( 3 ) ユークスの反応性が高くなると，レースウェイ内の 燃焼焦点の位置 $\left(\mathrm{CO}_{2}\right.$ 濃度のピークの位置)か羽口側に移行す る。

(4) 高反応性コークスを使用すると，レースウエイ内で のコークスの反応は塊コークスの表面に集中し, 反応劣化 層が薄くなる。

( 5 ) 微粉炭多量吹き込み時のレースウェイでのコークス の劣化を抑制するには，高強度で高反応性のコークスの使 
用が有効である。

\section{文献}

1) 稻葉些一，八木順一郎：鉄と鋼，78 (1992), 1187.

2 ) 附川維人, 後藤哲也, 伊藤良二, 矢場田武, 清水正賢 : R\&D

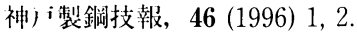

3 ）、1:條縌雄, 高橋 昇, 星野剛一, 吉田康夫, 伊藤良二, 柴田耕一朗, 川 裕：材料とプロセス, 6 (1993), 848

4 ）大鈴完二, 北山修二, 矢場田武, 清水正賢, 野間文雄: 材料 $と 7^{\circ}$ 口セス, 4 (1991), 100.

5 ）野沢健太郎, 宮川一也, 小野玲児, 上條綱雄, 清水正賢 : 材料 プロセス, 7 (1994), 961.

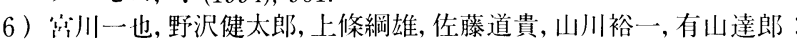
材料とプロセス, 7 (1994), 128.

7 ）们川達郎, 仵藤道貴, 村井亮太, 宮川一也, 野沢健太郎, 上條綱雄：
鉄と鋼， 81 (1995), 1114 .

8 ）山縣千里，須山真一，堀坂 修，梶原我雅：作友食屈，44 (1992) $1,36$.

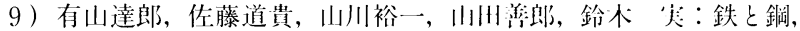
80 (1994), 288.

10）山口一良，上野浩光，田村健二：鉄と銅，78 (1992), 1214.

11）一田守政, 田村健二, 林洋一, 㠩微, 原川博, 杉川㑂： 製鉄研究，(1989)335, 7 .

12）原行明，中村正利，小自鸿次郎：製鉄研究，(1978)295, 12610

13）斎藤武文，岡本晋也，北村雅问：鉄々鎆，71 (1985), S92.

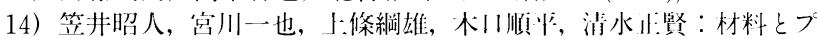
ロセス, 8 (1995), 957

15）野沢健太郎，上條綱雄，清水正賢：鉄と䤱，81 (1995), 882.

16）武田幹治，石渡夏生，内山 武，权谷 厷，F.C.Lockwood：材 料とプロセス, 9 (1996), 2.

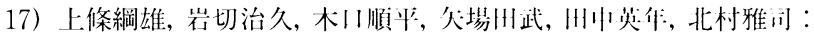
鉄と鋼, 73 (1987), 2012. 